\title{
Processes of Heat and Mass Transfer during Drying of Red Beetroot
}

\author{
Zhanna Petrova, Kateryna Samoilenko*, Vitaly Vishnevsky \\ Institute of Engineering Thermophysics of NAS of Ukraine, 2 Bulakhovskogo St., Kyiv, 03164, Ukraine
}

Received: May 19, 2020. Revised: June 25, 2020. Accepted: July 02, 2020.

(C) 2020 The Authors. Published by Lviv Polytechnic National University.

\begin{abstract}
Red beetroot is the main raw material which has a high content of betanine with antioxidant properties. An important emphasis in the processing of antioxidant raw materials by drying is to reduce energy consumption for the dehydration process, the maximum preservation of biologically active substances, and to reduce the cost of the final product. Drying is a complex and energy-intensive process. Therefore, to optimize energy consumption during drying and selection of rational modes of dehydration, it is necessary to apply the calculated analysis of heat and mass transfer on the basis of adequate mathematical models. Calculated and experimental results are compared. In general, the comparison of the results of numerical modeling of convection drying processes of the red beetroot sample with the experimental results showed their rather satisfactory qualitative agreement. The calculation model can be used to approximate the characteristics of the drying process of red beetroot, in particular the time required for drying. The obtained results of calorimetric studies allow stating that with correctly selected compositions, not only the components of native raw materials are stabilized, but also the drying process is intensified with the reduction of energy consumption to process.
\end{abstract}

Keywords: drying; heat of evaporation; heat and mass transfer; red beetroot.

\section{Definition of the problem to be solved}

The problem of processing, drying and use of vegetable raw materials with full preservation of their functionality is very relevant due to their widespread use in the food and pharmaceutical industries. One of the most effective ways to increase the shelf life of food is dehydration. Drying as one of the methods of processing of plant material is a complicated and energy-intensive process. The share of drying processes in the total energy balance and the volume of dried products is constantly increasing. The worldwide long-term experience of providing food to the public shows that the technologies and technical means that carry out the drying process are constantly refined and updated. This is due to the intensification and optimization of the heat engineering conditions of drying to maximize the preservation of the components of the raw material and obtain the final product with certain qualitative characteristics.

Betanine of red beetroot is destroyed by high temperatures, light, oxygen. The $\mathrm{pH}$ of red beetroot is 6-7. To preserve betanine during and after red beetroot drying, it is necessary to create an acidified environment in the range of $\mathrm{pH}$ 3.2-4.0. For this purpose, at the stage of preparation of raw materials for drying, red beetroot were combined with vegetable raw materials with high content of organic acids (rhubarb, tomato) in different ratios to obtain the optimal $\mathrm{pH}$ value. As a result, beet-rhubarb (2:1) and beet-tomato (3:1) compositions were obtained.

Optimizing costs at drying and selection of energy-efficient mode parameters of dehydration of antioxidant raw materials is possible due to the analysis of heat and mass transfer. Modern development and application of numerical methods for mathematical calculations allows modeling complex non-stationary processes of heat and mass transfer.

\footnotetext{
* Corresponding author. Email address: SamoilenkoKM@nas.gov.ua
}

This paper should be cited as: Z. Petrova, K. Samoilenko, V. Vishnevsky. Processes of heat and mass transfer during drying of red beetroot. Energy Engineering and Control Systems, 2020, Vol. 6, No. 2, pp. 81 - 87. https://doi.org/10.23939/jeecs2020.02.081 
Therefore, it is important to apply adequate mathematical models to optimize technological processes when drying red beetroot.

\section{Analysis of the recent publications and research works on the problem}

According to the literature [1], this area has a limited amount of information and therefore requires in-depth study and it is a currently important area of research.

\section{Formulation of the goal of the paper}

Red beetroot-rhubarb and red beetroot-tomato compositions are complex biochemical systems. Modern methods for calculating mathematical models do not allow formulating numerical modeling for such complex systems. Red beetroot is the basis of the studied compositions, so numerical modeling were performed for red beetroot, and experimental studies to determine the heat of evaporation, drying and storage of betanine after dehydration were performed for untreated red beetroot, red beetroot hydrothermally treated in acidified medium, red beetroot-rhubarb and red beetroot-tomato compositions. The main task is to determine the possibility of applying the mathematical model of heat and mass transfer A.V. Lykova to calculate the characteristics of the process of drying red beetroot and the formulation of boundary conditions and the construction of an appropriate numerical algorithm for modeling this process. This will make it possible to study the patterns of these processes, as well as to improve existing and develop new technologies for convective drying of red beetroot.

\section{Presentation and discussion of the research results}

\subsection{Modeling of heat and mass transfer in the process of drying red beetroot}

To determine the characteristics of the process of convective drying of antioxidant raw materials, numerical modeling of this process is performed. Modeling is performed based on numerical solution of the system of heat and mass transfer equations in colloidal capillary - porous materials [2]. The convection drying process involves the supply of heat by convection from the heated air stream to the material to be dried. The material, having the shape of a rectangular parallelepiped with a thickness of $\mathrm{d}$, is in the drying chamber, which is fed to the heated coolant. The coolant flows around the sample material symmetrically on two sides. Moisture from the heat and mass transfer surfaces is removed into the air stream in the form of steam.

The system of heat and mass transfer equations consists of the equation of moisture transfer [3]-[4]

$$
\frac{\partial U}{\partial \tau}=\operatorname{div}\left(a_{m} \operatorname{grad}(U)\right)+\operatorname{div}\left(a_{m} \delta_{t} \operatorname{grad}(T)\right)
$$

and a heat transfer equation that takes into account the heat of evaporation of moisture inside the material

$$
c \rho \frac{\partial T}{\partial \tau}=\operatorname{div}(\lambda \operatorname{grad}(T))+r \varepsilon \frac{\partial U}{\partial \tau},
$$

where $U, \mathrm{~kg} / \mathrm{m}^{3}$ is specific moisture content of the material (total mass of liquid moisture and water vapor per unit volume of material); $T, \mathrm{~K}$ is temperature; $\tau$, $\mathrm{s}$ is time; $a_{m}, \mathrm{~m}^{2} / \mathrm{s}$ is moisture diffusion coefficient in capillary-porous material; $\delta_{t}, \mathrm{~kg} /\left(\mathrm{m}^{3} \cdot \mathrm{K}\right)$ is thermogradient coefficient; $c, \mathrm{~J} /(\mathrm{kg} \cdot \mathrm{K})$ is effective heat capacity of the material; $\rho, \mathrm{kg} / \mathrm{m}^{3}$ is effective material density; $\lambda$ is effective thermal conductivity of the material; $r, \mathrm{~J} / \mathrm{kg}$ is specific heat of evaporation; $\varepsilon$ is phase transformation coefficient, which characterizes the ratio of water vapor flow to total liquid moisture flow and vapor flow, its value varies from 0 to 1 .

The problem is considered in one-dimensional formulation. The process is considered symmetric with respect to the plane of symmetry of the rectangular sample. For the case of a relatively small sample thickness $d$ and at low temperature gradients, moisture transfer by thermal diffusion can be neglected. Initial and boundary conditions are set to solve the system of nonstationary heat and mass transfer equations. The initial temperature $T_{0}$ and moisture content of the material $U_{0}$, which are evenly distributed over its thickness, are known. The speed $U_{\infty}$, temperature $T_{\infty}$ and 
relative humidity $\varphi_{\infty}$ of the coolant at the inlet to the drying chamber are also known. On the contact surface of the coolant with the material to be dried, the boundary conditions of the third kind are set, which establish the equality of mass flow densities emanating from the material and entering the coolant

$$
-\left.a_{m} \frac{\partial U}{\partial x}\right|_{x=d / 2}=\beta\left(C_{v, w}-C_{v, \infty}\right)
$$

and equality of heat flux densities on the heat and mass transfer surface

$$
-\left.\lambda \frac{\partial T}{\partial x}\right|_{x=d / 2}=\alpha\left(T_{w}-T_{\infty}\right)+r\left(1-\varepsilon_{w}\right) \beta\left(C_{v, w}-C_{v, \infty}\right),
$$

where $x$ is direction from the plane of symmetry of the sample, for which $x=0$, to the heat and mass transfer surface, for which $x=d / 2 ; C_{v, w}$ is the relative concentration of water vapor in the coolant near the surface of heat and mass transfer; $C_{v, \infty}$ is the relative concentration of water vapor in the coolant at a considerable distance from the surface; $T_{w}$ is temperature of surface of heat and mass transfer; $T_{\infty}$ is the temperature of the coolant at a considerable distance from the surface; $\alpha, \mathrm{W} /\left(\mathrm{m}^{2} \cdot \mathrm{K}\right)$ is heat transfer coefficient; $\beta, \mathrm{kg} /\left(\mathrm{m}^{2} \cdot \mathrm{s}\right)$ is mass transfer coefficient.

Heat transfer coefficient $\alpha$ is determined from the similarity equation for the Nusselt number in turbulent flow around a flat surface. An approximate expression $\beta \approx \alpha / C_{a}$ is used to determine the mass transfer coefficient $\beta$, which follows from the analogy between heat transfer and mass transfer in the boundary layer. These boundary conditions for wet material take into account the heat of evaporation of liquid moisture from the surface. To set the conditions of convection mass transfer from the surface of the material, the value of the concentration of water vapor near its surface is determined. In the case where the moisture content of the material near the mass transfer surface exceeds the value of the maximum hygroscopic moisture content, the concentration of water vapor is determined from the conditions for saturated vapor at the temperature of this surface. If the moisture content of the material near the surface is less than the maximum hygroscopic value, the concentration of water vapor $C_{v, w}$ is determined from the sorption isotherm by the values of moisture content and temperature at the surface. In the symmetry plane, the mass and heat flux densities are considered to be zero. The system of equations together with the boundary conditions is solved by the method of finite differences according to an implicit scheme. As a result, we obtain time-dependent distributions of temperature and moisture content over the thickness of the material to be dried, as well as other characteristics of the convection drying process. The dependence of the total mass of moisture $m_{w}$ in the sample on time is also determined as follows

$$
m_{w}(\tau)=2 F \cdot \int_{0}^{d / 2} U(\tau, x) d x
$$

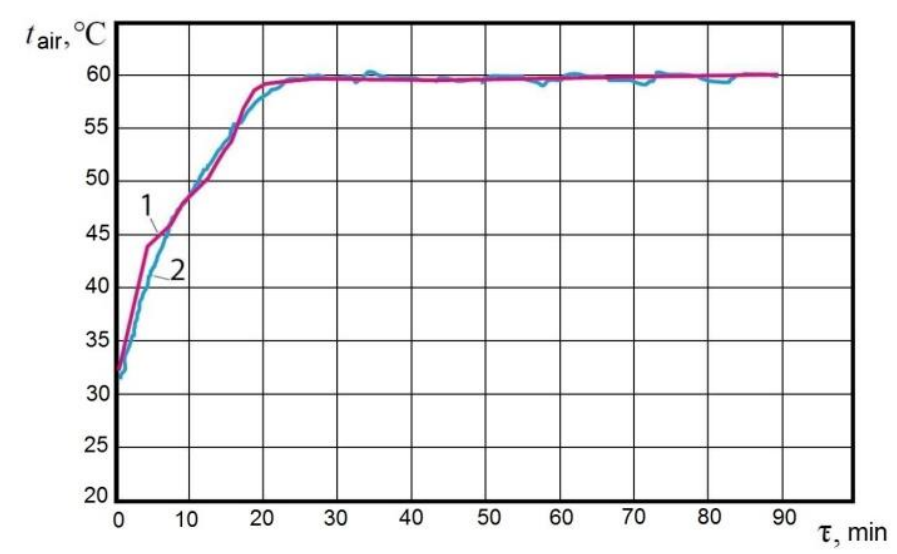

Fig.1. Dependence of heat and mass transfer surface temperature on time during its drying: 1 - experimental data; 2 - calculation results. 
As an example, we consider the results of a numerical study of the process of convective drying of the sample with a thickness of $d=10 \mathrm{~mm}$ and the surface area from which moisture is removed, $F=1000 \mathrm{~mm}^{2}$. Air flow speed in the drying chamber $u_{\infty}=3.5 \mathrm{~m} / \mathrm{s}$, temperature $T \infty=60^{\circ} \mathrm{C}$, relative humidity $\varphi \infty=4.7 \%$. Initial mass of the sample $m_{0}=m_{w, 0}+m c=9.786 \mathrm{~g}$. Its initial temperature $T_{0}=26.6{ }^{\circ} \mathrm{C}$. Mass of dry material $m_{c}=1.41 \mathrm{~g}$. The initial specific moisture content $U_{0}=837.6 \mathrm{~kg} / \mathrm{m}^{3}$.

Thermophysical properties of red beetroot, as well as the dependence of the equilibrium moisture content of raw materials on the relative humidity (sorption curves) are determined from studies [5]. According to the initial data, in addition to computational studies, experimental studies were also conducted to compare their results. The drying process of the sample lasted 90 minutes. The results of comparing dependences of heat and mass transfer surface temperature on time and the moisture mass in the sample during its convection drying are shown in Fig.1 and Fig.2.

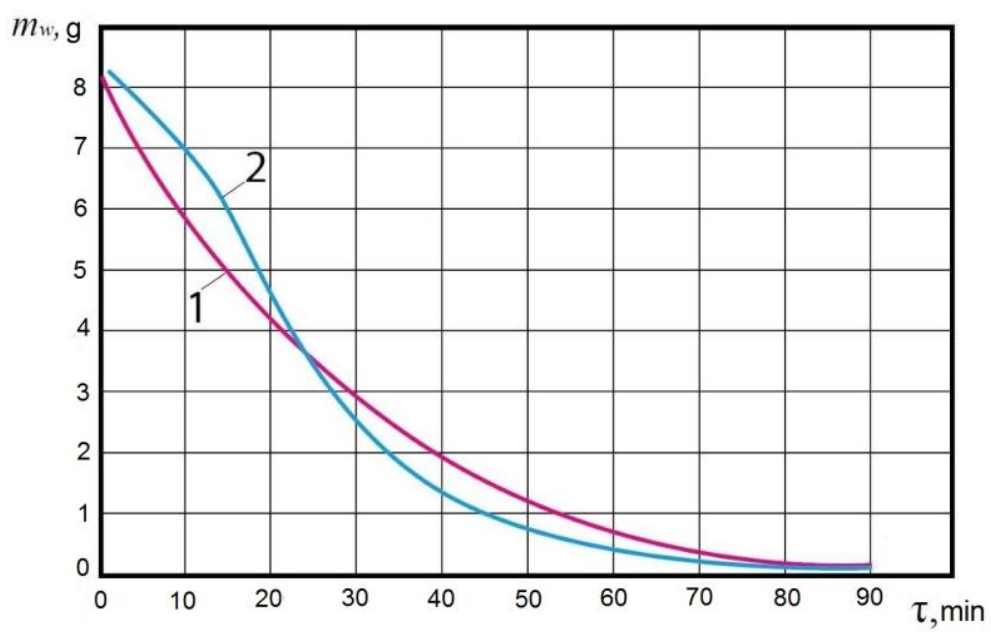

Fig.2. Dependence of moisture mass in the sample on time during its drying:

1 - experimental data; 2 - calculation results.

A comparison of the calculated and experimental results shows that according to this numerical model, the drying process at the initial stage is somewhat slower than it follows from the experiment. In the future, the intensity of drying of the material, which is determined from the calculations, is greater than that obtained from the experiment (Fig. 2).

In general, the comparison of the results of numerical modeling of convection drying processes of red beetroot with the experimental results showed their rather satisfactory qualitative agreement. Therefore, the considered calculation model can be used to approximate the characteristics of the drying process of red beetroot, in particular, the time required for drying.

\subsection{Investigation of the heat of evaporation of antioxidant raw materials}

When calculating energy costs for the drying process, in addition to time, it is necessary to know the specific heat consumption for water evaporation. The practice of drying complex plant materials indicates a significant difference between the actual values consumption of heat on evaporation of moisture from them and the heat of evaporation of pure water [6]-[7]. Since the increase in energy costs for drying plant materials is associated with difficult permeability of cell membranes to water and the difficulty of removing water that interacts with soluble molecules of cell sap and skeletal molecules of the material, it was important to investigate the effect of functional compositions of plant raw materials on heat evaporation [8]-[10].

The differential method of measurement has been widely used in calorimetry due to the ability to significantly reduce the influence of external factors on the final measurement result. A typical example of a device with a differential method of measurement in calorimetry in the study of the specific heat of evaporation is the device DMKI-1, which was designed in Institute of Engineering Thermophysics of NAS of Ukraine. This device implements 
the principle of synchronous thermal analysis, which combines differential calorimetric and gravimetric measurement methods. The drying process takes place inside the thermal unit DMKI-01 at the optimum temperature of $60^{\circ} \mathrm{C}$.

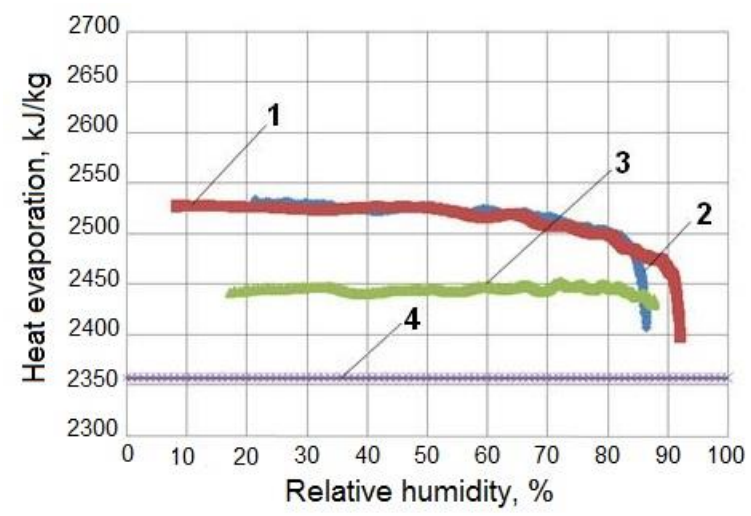

Fig.3. Comparative characteristics of the heat of evaporation of water from antioxidant raw materials based on red beetroot with rhubarb $\left(\mathrm{t}=60^{\circ} \mathrm{C}, \mathrm{v}=0.8 \mathrm{~m} / \mathrm{s}, \mathrm{d}=10 \mathrm{~g} / \mathrm{kg}\right)$ :

1 - rhubarb; 2 -red beetroot; 3 - red beetroot-rhubarb (2:1); 4 - water.

Figure 3 shows that the heat of evaporation of moisture from the red beetroot-rhubarb mixture is approximately $10 \%$ less than the heat of evaporation of moisture from red beetroot or rhubarb separately. It can be assumed that the activity of rhubarb acids has a chemical effect on the permeability of the cell membrane of red beetroot, which increases moisture transfer, moisture from the cell evaporates more intensely and, consequently, reduces the heat of evaporation and reduces the amount of bound moisture.

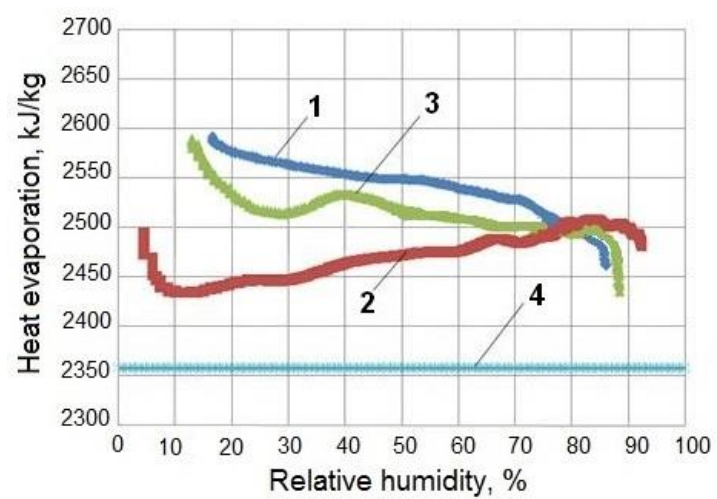

Fig.4. Comparative characteristics of the heat of evaporation of water from antioxidant raw materials based on red beetroot with tomato $\left(\mathrm{t}=60^{\circ} \mathrm{C}, \mathrm{v}=0.8 \mathrm{~m} / \mathrm{s}, \mathrm{d}=5 \mathrm{~g} / \mathrm{kg}\right)$ :

1 - red beetroot; 2 - tomato; 3 - red beetroot-tomato $(3: 1) ; 4$ - water.

Fig. 4 shows the values of the heat of evaporation of moisture with red beetroot, tomato, red beetroot-tomato compositions in comparison with each other and the heat of evaporation of pure water. The values of specific heat consumption for evaporation from the red beetroot-tomato mixture (3:1) during drying are between the values of specific heat consumption for evaporation from red beetroot and tomato separately.

As a result of differential studies, it was found that the heat of evaporation of water in the red beetroot-rhubarb composition is $10-12 \%$ less than the original components of the raw material; the heat of evaporation of the red beetroot-tomato composition is $4-5 \%$ lower than the heat of evaporation of red beetroot.

\subsection{Investigation of the dependence to preservation of betanine of red beetroot to the coolant temperature}

Investigation of the effect of coolant temperature on the change of betanine content in red beetroot were performed on raw red beetroot, red beetroot hydrothermally treated in an acidified environment and created red beetroot-rhubarb and red beetroot-tomato compositions. As can be seen from Figure 5, when raw red beetroot drying, betanine preservation at $40 \%$ (Fig. 5). 


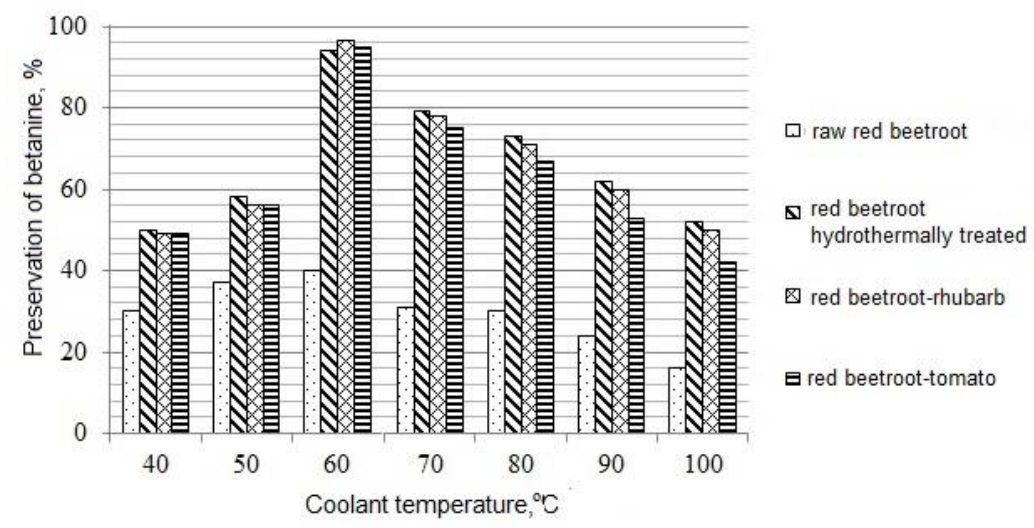

Fig.5. Dependence of betanine preservation on coolant temperature.

At a coolant temperature of $40-50{ }^{\circ} \mathrm{C}$ and high moisture content, even hydrothermally treated red beetroot spoil, and betanine is stored only by $40-50 \%$. At a coolant temperature of $70-80{ }^{\circ} \mathrm{C}-$ about $70 \%$ of betanine is stored. The maximum value of betanine preservation of $96.5 \%$ corresponds to the drying mode of $60{ }^{\circ} \mathrm{C}$ and the created compositions.

\section{Conclusion}

Comparison of the results of numerical modeling of convective drying processes of red beetroot with experimental results showed their rather satisfactory qualitative agreement. At the same time, there is a certain discrepancy in the quantitative indicators of these results. Therefore, the considered calculation model based on the proposed system of equations can be used to approximate the characteristics of the drying process of red beetroot, in particular the time required for drying. As a result of calorimetric studies, it is proved that the evaporation heat of the antioxidant composition is lower than the evaporation heat of red beetroot. As shown by studies of the dependence of betanine of red beetroot on the coolant temperature, the maximum value of betanine preservation corresponds to the drying regime of $60{ }^{\circ} \mathrm{C}$ and the created red beetroot-rhubarb and red beetroot-tomato compositions.

\section{References}

[1] Sorokova N.M. (2004) Modeling of heat and mass transfer during dehydration of porous bodies in order to optimize the drying process. Abstract of the dissertation of the candidate of technical sciences. Institute of Engineering Thermophysics of NAS of Ukraine. Kyiv p. 20 (in Ukrainian)

[2] Petrova Zh.O., Davydenko B.V., Slobodyaniuk K.C. (2019) Modeling of heat and mass transfer in the process of drying of colloidal capillary-porous materials. Journal "Ceramics, Science and Life", No. 2 (43), pp. 7-14. (in Ukrainian)

[3] Lykov A.V., Myhailov U.V. (1963) Theory heat and mass transfer. Moscow, Gosnernergoizdat. pp. 55-57. (in Russian)

[4] Dolinskiy A. A., Dorfman A. Sh., Davydenko B. V. (1991) Conjugate heat and mass transfer in continuous processes of convective drying. Int. J. Heat Mass Transfer, V.34, No. 11. pp. 2883-2889.

[5] Petrova Zh.O., Sniezhkin YU.F, Getmanyuk K.M. (2014) Investigation of adsorption processes of antioxidant plant powders. Scientific works Odessa National Academy Food Technolodgies, Iss. 45, V. 2, pp. 21-25 (in Ukrainian)

[6] Dmytrenko N.V., Dubovikova N.S., Sniezhkin YU.F, Mykhailyk V.A., Dekusha L.V., Vorobiov L.I. (2011) Study of the influence of water in food plant materials on the heat of evaporation. Scientific works Odessa National Academy Food Technolodgies, Iss. 40. V. 2, pp. 71-75 (in Ukrainian)

[7] Ginzburg A.S., Gromov M.A., Krasovskaya G.I. (1980) Thermophysical characteristics of food products. Directory, Moscow «Food industry», p. 288. (in Russian)

[8] Sniezhkin YU.F, Petrova Zh.O., Dmytrenko N.V., Getmanyuk K.M. (2013) Study of the influence of pre-arrangement of vegetable raw materials on the quality of dry product and heat of evaporation. Scientific works Odessa National Academy Food Technolodgies, Iss. 43, V. 2, pp. 4-6 (in Ukrainian)

[9] Petrova Zh.O., Sniezhkin YU.F, Samoilenko K.M. Investigation of evaporation heat from betanine-containing vegetable raw materials in the process of dehydration by the method of synchronous thermal analysis. Scientific works Odessa National Academy Food Technolodgies, Iss. 47, V. 2, pp. 33-38 (in Ukrainian)

[10] Ivanov S.A., Samoilenko K.M. (2017) Correction of the influence of unequal heat transfer conditions in cells when studying the heat of evaporation on a differential calorimeter. Journal «Scientific look into the future», Odessa, Iss. 5, V. 1, pp. 63-67. (in Russian) 


\title{
Процеси тепломасопереносу при сушінні столового буряка
}

\author{
Жанна Петрова, Катерина Самойленко, Віталій Вишнєвський \\ Інститут технічної теплофізики НАН Украӥни, вул. Булаховського, 2, м. Київ, 03164, Украӥна
}

\begin{abstract}
Анотація
Основною сировиною, яка має високий вміст бетаніну з антиоксидантними властивостями, є червоний столовий буряк. Важливим акцентом при переробці антиоксидантної сировини методом сушіння є зниження енергозатрат на процес зневоднення, максимальне збереження біологічно активних речовин та зниження собівартості кінцевого продукту. Сушіння - це складний і енергоємний процес. Тому для оптимізації витрат енергії при сушінні та підбору раціональних режимів зневоднення необхідно застосовувати розрахунковий аналіз тепломасообміну на основі адекватних математичних моделей. Застосування математичної моделі тепломасопереносу А. В. Ликова дало можливість побудувати відповідний чисельний алгоритм для моделювання цього процесу, виконати чисельні дослідження процесу конвективного сушіння столового буряка. Розрахункові та експериментальні результати порівнюються. Вцілому, порівняння результатів чисельного моделювання процесів конвекційного сушіння зразка столового буряка 3 експериментальними результатами показало їх достатньо задовільне якісне узгодження. Розрахункова модель може використовуватися для наближеного визначення характеристик процесу сушіння столового буряка, зокрема часу, необхідного для сушіння. Отримані результати калориметричних досліджень дозволяють стверджувати, що при правильно підібраних композиціях вони не лише стабілізують компоненти нативної сировини, а й відбувається інтенсифікація процесу сушіння із зменшенням енерговитрат на процес.
\end{abstract}

Ключові слова: сушіння; теплота випаровування; тепломасоперенос; столовий буряк. 